\title{
APPLICATION OF SYSTEM MODELING AND THE SIMULATION OF PHOTOVOLTAIC PRODUCTION
}

\author{
Raja Glaa', Nafaa Jeddi', Najeh Lakhoua', Lilia El Amraoui ${ }^{1}$ \\ 1 Research Unit Signals and Mechatronic Systems, SMS, UR13ES49, National Engineering School of Carthage, \\ ENICarthage, University of Carthage, Tunisia, e-mail: rajaaglaa@gmail.com, nafaa.jeddi@enicarthage.rnu.tn, \\ MohamedNajeh.Lakhoua@ieee.org, lilia.elamraoui@enicarthage.rnu.tn
}

Received: 2017.05.15

Accepted: 2017.08.01

Published: 2017.09.03

\begin{abstract}
The major goal of electric power companies is to give the quantity of electricity claimed by each consumer. This does not function without posing problems because consumption increases with time and the production will not be adequate to cope with the need for electricity. Besides, we may face environmental issues such as the increase of $\mathrm{CO}_{2}$ in the world, the conditions of producing energy, the difficulty of easily, quickly and economically storing large quantities of electricity. One of the solutions that could restrict and solve the problems is the production of renewable energy. In this paper, we focus on photovoltaic products; we present the photovoltaic conversion chain such as modeling, adaptation and control systems, as well as photovoltaic characteristics and system analysis methodology and planning of a photovoltaic system based on the OOPP method (Objectives Oriented Project Planning).
\end{abstract}

Keywords: photovoltaic systems, Maximum Power Point Tracking (MPPT), systemic modelin, OOPP method.

\section{INTRODUCTION}

For hundreds of years, man has made enormous innovations that appeal to technological progress in all areas (electronics, automation, computer...) to improve living standards and make life easier. However, the progression of technology and the improvement of manual systems to automated systems are a very important call to electricity.

That is why researchers are making great efforts to improve the production of electricity, switch between production and demand and assure monitoring and real time supervision of all environmental changes to the power grid by a very intelligent network called Smart-grid.

The smart grid contains seven areas, the most important is the production area, which is a large research area generally based on renewable sources such as water, wind and sun.
In this article, we will be interested in photovoltaic generation for which a systemic modeling method Objectives Oriented Project Planning (OOPP) is presented to give a good description of this system. This is how research on chain photovoltaic conversion and Matlab simulation on the characteristics of a photovoltaic module are presented.

\section{CHAIN PHOTOVOLTAIC CONVERSION}

A photovoltaic panel (PV) is used either to directly operate a continuous load current, or connect to a public network, or both (Figure 1).

In this section, we identify the different blocks of a photovoltaic conversion chain. We start by modeling a PV panel and then adapting the system by static converter DC-DC, along with ordering the system with the approach perturbation and observation, and finally adapting the system using static conversion DC-AC. 


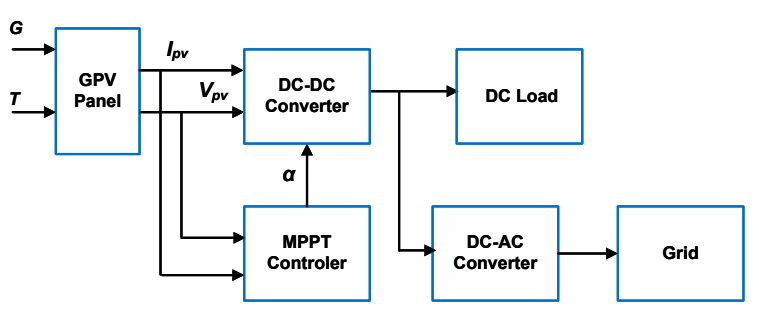

Fig. 1. Blocks of photovoltaic conversion chain

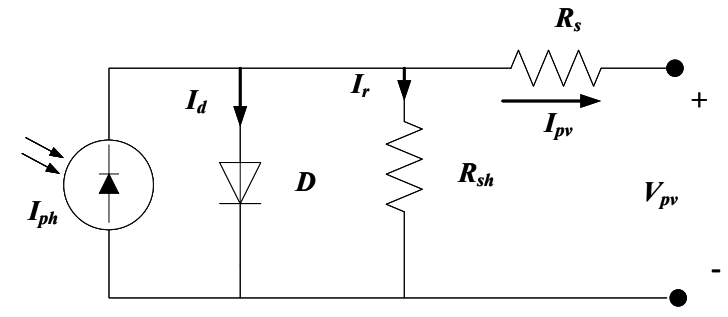

Fig. 2. Equivalent electric diagram of a PV cell [1]

\section{Modeling of a photovoltaic module}

Photovoltaic solar energy is the direct conversion of energy from photons into electricity. The combination of several PV cells called module and the combination of several modules form a PV panel [19,21].

The cell of a PN junction photovoltaic submitted to the illumination can be schematized in Fig. 2 [22, 24]. The equivalent electric diagram of a PV cell can be modeled by equation (1):

$$
I_{p v}=I_{p h}-I_{d}-I_{r}
$$

Where: The photocurrent of the cell proportional to the sunning $\mathrm{E}_{\mathrm{s}}$ is given by equation (2):

$$
I_{p h}=I_{c c}\left(\frac{E_{s}}{1000}\right)
$$

The current through the diode is given by the equation (3):

$$
I_{d}=I_{s a t}\left(\mathrm{e}^{\left(\frac{q\left(V_{p v}+I_{p v} R_{s}\right.}{A K T}\right)}-1\right)
$$

The current derived from the shunt resistance is given by equation (4):

$$
I_{r}=\frac{V_{p v}+\mathrm{I}_{p v} R_{s}}{R_{s h}}
$$

From equation (1), a simple methodology was developed to determine the characteristics of a cell or photovoltaic panel, such as short-circuit current $\mathrm{I}_{\mathrm{cc}}$ and the open circuit voltage $\mathrm{V}_{\mathrm{oc}}$ to infer the implicit mathematical expression of the current delivered by a photovoltaic cell, and its characteristic I-V.

Similarly, for mathematical modeling of a PV panel, we must have the actual realization of the module structure, such as the inclusion of cells in a PV module in the three following types [7, 10]:

- The cells are associated in series: The series connection of PV cells Ns delivers a voltage equal to the sum of the individual voltages and a current equal to that of a single PV cell.

- The cells are associated in parallel: The parallel combination of the PV panels delivers a current equal to the sum of the individual currents and a voltage equal to that of a single PV cell.

- The cells are associated in parallel and in series "mixed", in order to increase the current and voltage.

- In general, the modeling of a PV panel is presented by equation (5) [12].

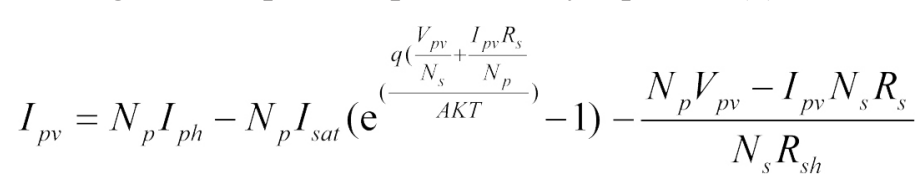

\section{Adaptation system by the DC-DC converter}

The converter is used to adapt the energy from the PV panel with load. In the case of a booster converter, the nature of the voltage does not change but the voltage level increases. In order to make the converter operate in a continuous conduction mode, the IGBT must be open and the current going through the inductor is not canceled (Figure 3) $[1,6]$. 


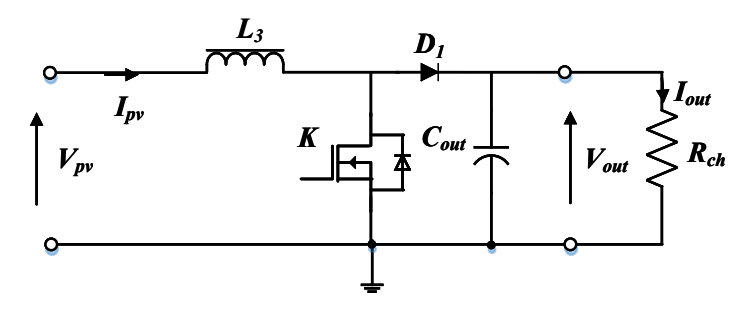

Fig. 3. Typical structure of DC-DC boost converter

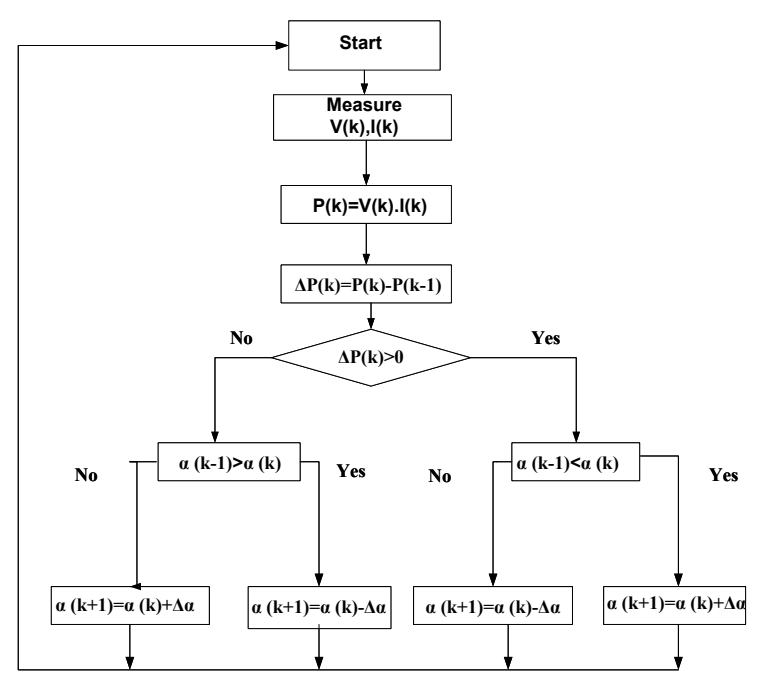

Fig. 4. Flow chart of $\mathrm{P} \& \mathrm{O}$ algorithm

In this case, the division of the output voltage of the chopper by its input voltage is equal to [4]:

$$
\frac{V_{o u t}}{V_{p v}}=\frac{1}{1-\alpha}
$$

With $\alpha$ : the duty cycle.

The nonlinear characteristic of the PV module and sensitivity to external conditions induces energy losses hence the fluctuation of the output voltage can damage the load. The importance of a control system is essential.

\section{Ordering system with the approach perturbation and observation}

Command systems that are mentioned later in systems analysis have the same purpose; it is the search of the maximum power point tracking MPPT. However, the performance, implementation, complexity and rapidity will differ from algorithm to another.

The photovoltaic panels are subjected to changing conditions in sunshine and temperature. These changes materialize the need of a power

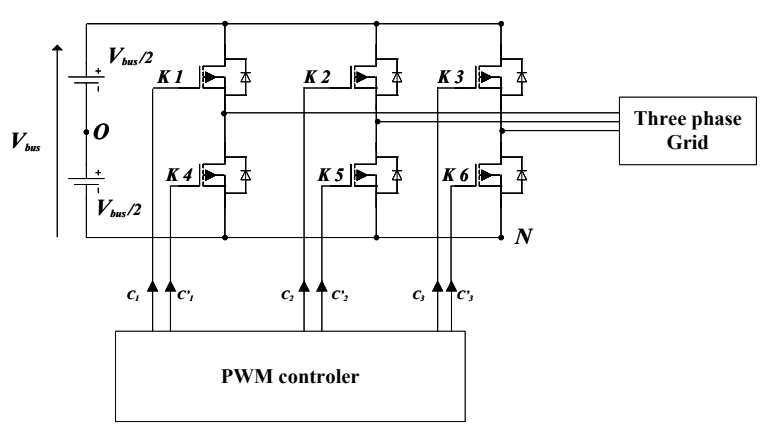

Fig. 5. Three phase voltage inverter connected to a grid

extraction optimization algorithm that is changing the values of voltage and current of the photovoltaic generator to MPPT $[5,9]$.

The algorithm studied in this research is the perturbation approach and observation that changed in a block diagram (Figure 4). The command offered by this approach obliges the operating point of the photovoltaic generator to approach the maximum power point and oscillate around it either by a linear positive or negative variation in voltage of the photovoltaic generator through time [25].

\section{Adaptation system by converter DC-AC}

The DC-AC converter is used to adapt the energy from the PV panel either directly or by the intermediary of a Boost converter. This converter changes the nature of the continuous voltage to the alternative and stabilizes the voltage level after the PV panel. It can be a mono-phase for operating charges or three-phases for delivering energy to the grid (Figure 5) $[8,11]$.

\section{SYSTEM MODELING OF PHOTOVOLTAIC CONVERSION CHAIN}

Analysis of a PV generator with system method OOPP allows us to scale a PV system with a study that contains the best choice of components according to the charge and the installation site.

\section{Presentation of method}

The OOPP method is considered a communication device, an analysis and project planning, whatever its nature and its location $[2,3]$. It is comprised of three essential stages: problem analysis stage; objective analysis stage and stage of activity planning. 
The problem analysis stage is very frequent that the conception and implementation of a project meets a problematic situation expressed by a sponsor.

The approach used is Federative since it endorses the principle of organizing workshops bringing together a variety of competence domain. This is how the analysis of this situation must be conducted according to a structured methodology based on causal logic identifying their effects and causes (Figure 6) [13, 14, 15].

The objectives of the analysis process are presented by the Tree of problems constituting in a negative report. It allows a simple inversion (transform a negative state to a positive state) to build a Tree of Objectives which constitute the basis of any plan of Action [20,23].

A causal logic of problem analysis, it is made logical to correspond "means-end" for developing the objectives tree. This is how we establish connections:

- Central Problem: PC $\rightarrow$ Global Objective: OG

- Direct Cause: DC $\rightarrow$ Specific Objective: OS

- Sub-Cause: $\mathrm{SC} \rightarrow$ Result: R

- Sub-Sub Cause: SSC $\rightarrow$ Activity: A

To analyze an objective, a result, an activity or a derived activity, is arisen whenever we are confronted with the question: What is to be done to achieve the discussed objective or achieve the result should we perform the identified activity?

The answer to this question is brought about by the decomposition of the level of analysis in the lower levels $[16,17]$.

The OOPP method allows, in addition to the determination of the different steps in the analysis of a project [18] from:

- Follow its evolution,

- Evaluate the project at its various stages,

- Identify dysfunctions and deviations between performance and planning,

- Analyze the causes,

- Identify the responsibility.

\section{Modeling of the photovoltaic conversion chain by OOPP method}

With the smart grid, the production domain becomes very complex: Firstly, the consumer participates in the production of the electricity "Prosumers". He can use his own production and if there is a higher production than its consumption, it will be sold or stored in a battery. Secondly, the unidirectional direction of the electrical network and the data information between the production
Table 1. Specific Objective OS1

\begin{tabular}{|c|c|l|}
\hline 1 & OS1 & $\begin{array}{l}\text { Modes of exploitation photovoltaic panels } \\
\text { studied }\end{array}$ \\
\hline 2 & R1.1 & Autonomous mode studied \\
\hline 3 & A1.1.1 & $\begin{array}{l}\text { Studying the autonomous modes without } \\
\text { storage }\end{array}$ \\
\hline 4 & A1.1.2 & $\begin{array}{l}\text { Studying the autonomous modes with } \\
\text { storage }\end{array}$ \\
\hline 5 & R1.2 & Mode connected to the network studied \\
\hline 6 & A1.2.1 & $\begin{array}{l}\text { Studying the modes directly connected to } \\
\text { public network }\end{array}$ \\
\hline 7 & A1.2.2 & $\begin{array}{l}\text { Studying the modes connected to the } \\
\text { public via a home }\end{array}$ \\
\hline 8 & R1.3 & Hybrid Mode studied \\
\hline 9 & A1.3.1 & Studying the mode hybrid PV / wind \\
\hline 10 & A1.3.2 & $\begin{array}{l}\text { Studying the mode hybrid PV / wind power } \\
\text { / diesel }\end{array}$ \\
\hline 11 & A1.3.3 & Studying mode hybrid PV / battery \\
\hline
\end{tabular}

domain and the operation domain are modified by a bidirectional direction. It is for this reason that we have chosen to analyze the PV production with the OOPP systemic method.

In this research, we use this method to study the production domain particularly the PV production, to manage its complexity, to evaluate the system in these different stages and to determine the different applications.

Identification of PV production is the general objective of system analysis (OG). This objective is presented in four tables; each one of them identifies a specific objective:

- OS1 to identify the modes of exploitation of the PV panels.

- OS2 to identify PV applications

- OS3 to identify the PV production cycle.

- OS4 to identify the variables of installation PV.

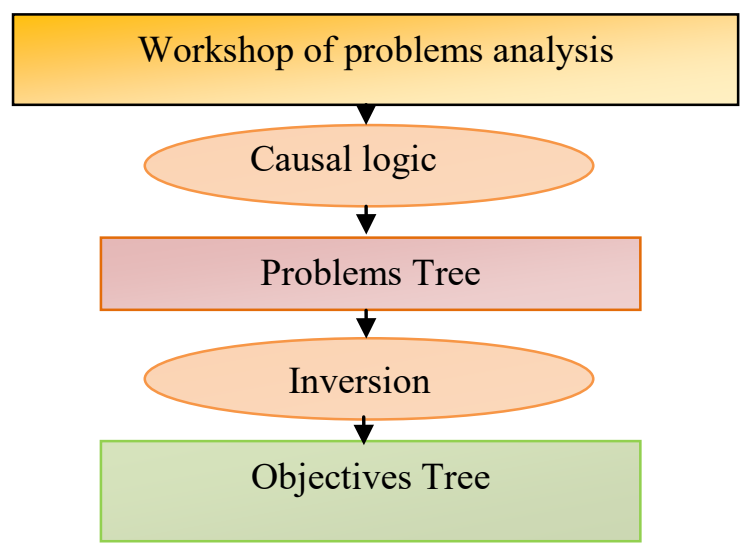

Fig. 6. OOPP method 
Table 2. Specific Objective OS2

\begin{tabular}{|c|c|l|}
\hline 1 & OS2 & Presented photovoltaic applications \\
\hline 2 & R2.1 & $\begin{array}{l}\text { Photovoltaic applications connected to the } \\
\text { network presented }\end{array}$ \\
\hline 3 & A2.1.1 & Introduce artificial satellites \\
\hline 4 & A2.1.2 & Introduce professional applications \\
\hline 5 & S2.1.2.1 & Present the Telecommunications Relay \\
\hline 6 & S2.1.2.2 & Present the Road Sign \\
\hline 7 & S2.1.2.3 & Present the terminals highway rescue \\
\hline 8 & S2.1.2.4 & Present the Remote monitoring of vehicles \\
\hline 9 & A2.1.3 & Introduce portable devices \\
\hline 10 & S2.1.3.4 & Present calculators \\
\hline 11 & S2.1.3.5 & Present the watches \\
\hline 12 & S2.1.3.6 & Present the telephone domains \\
\hline 13 & S2.1.3.7 & Present the microcomputers \\
\hline 14 & A2.1.4 & Introduce rural electrification of isolated sites \\
\hline 15 & R2.2 & $\begin{array}{l}\text { Photovoltaic application is not connected } \\
\text { to the networks presented }\end{array}$ \\
\hline 16 & A2.2.1 & Present the PV parks ground \\
\hline 17 & A2.2.2 & Present the systems attached to a building \\
\hline
\end{tabular}

\section{SIMULATION RESULTS AND DISCUSSION}

After modeling a photovoltaic panel by mathematical equations (presented in section: Modeling of a photovoltaic module) and presenting systemic modeling, we present a simulation of the characteristics of a photovoltaic panel using the Matlab environment. The model study of PV module contains 36 cells connected in series.

As it was identified earlier in the OOPP analysis, the photovoltaic efficiency influenced directly by the atmospheric conditions (temperature and solar irradiation).

To see the performance of the system and the influence of solar irradiation on the characteristics of a PV module, we set the temperature value at $25^{\circ} \mathrm{C}$ and varied the value of the solar irradiation of $400 \mathrm{~W} / \mathrm{m}^{2}$ up to $1000 \mathrm{~W} / \mathrm{m}^{2}$. The result of this variation (Figures 7 and 8) generates a significant increase in the value of the short-circuit current and a small increase of the voltage value.

The influence of temperature variation in the photovoltaic system characteristics (I-V and P-V) are presented in Fig. 9 and 10. In this case, we considered solar irradiation is constant at 1000 $\mathrm{W} / \mathrm{m}^{2}$ and the temperature values are variables between $10^{\circ} \mathrm{C}$ and $50^{\circ} \mathrm{C}$.

When temperature increases values, we interpret that the voltage and the power of the system decreases slightly, but the current is almost constant. So, the voltage is influenced directly by the temperature.
Table 3. Specific Objective OS3

\begin{tabular}{|c|c|c|}
\hline 1 & Os3 & Photovoltaic production cycle identified \\
\hline 2 & R3.1 & $\begin{array}{l}\text { Transformation of solar radiation into } \\
\text { electricity identified }\end{array}$ \\
\hline 3 & A3.1.1 & Identify the different photovoltaic cells \\
\hline 4 & S3.1.1.1 & Identify monocrystalline cells \\
\hline 5 & S3.1.1.2 & Identify polycrystalline cells \\
\hline 6 & S3.1.1.3 & Identify amorphous cells \\
\hline 7 & A3.1.2 & Modeling a photovoltaic cell \\
\hline 8 & S3.1.2.1 & $\begin{array}{l}\text { Determining the characteristics of a } \\
\text { photovoltaic cell }\end{array}$ \\
\hline 9 & T3.1.2.1.1 & Determine the short-circuit current \\
\hline 10 & T3.1.2.1.2 & Determine the open circuit voltage \\
\hline 11 & T3.1.2.1.3 & Determine the maximum power point \\
\hline 12 & T3.1.2.1.4 & Determine the maximum yield \\
\hline 13 & T3.1.2.1.5 & Determine the form factor \\
\hline 14 & S3.1.2.2 & Placing the cells depending on the load \\
\hline 15 & T3.1.2.2.1 & Grouping cells in parallel \\
\hline 16 & T3.1.2.2.2 & Grouping cells in series \\
\hline 17 & T3.1.2.2.3 & Grouping cells in series-parallel \\
\hline 18 & S3.1.2.3 & Model a photovoltaic panel \\
\hline 19 & R3.2 & $\begin{array}{l}\text { Voltage regulation according the load } \\
\text { used }\end{array}$ \\
\hline 20 & A3.2.1 & Use a DC-DC converter \\
\hline 21 & S3.2.1.1 & Using a boost converter \\
\hline 22 & S3.2.1.2 & Using a buck converter \\
\hline 23 & S3.2.1.3 & Using a buck-boost converter \\
\hline 24 & A3.2.2 & Use MPPT command \\
\hline 25 & S3.2.2.1 & $\begin{array}{l}\text { Using perturbation and observation } \\
\text { approach }\end{array}$ \\
\hline 26 & S3.2.2.2 & $\begin{array}{l}\text { Using the approach of open circuit and } \\
\text { short circuit }\end{array}$ \\
\hline 27 & T3.2.2.2.1 & $\begin{array}{l}\text { Use algorithm based of measuring a } \\
\text { fraction of the current Icc }\end{array}$ \\
\hline 28 & T3.2.2.2.2 & $\begin{array}{l}\text { Use algorithm based of measuring a } \\
\text { fraction of the voltage Voc }\end{array}$ \\
\hline 29 & S3.2.2.3 & $\begin{array}{l}\text { Use incrementing the conductance } \\
\text { approach }\end{array}$ \\
\hline 30 & S3.2.2.4 & Use artificial intelligence approach \\
\hline 31 & T3.2.2.4.1 & Using neural networks \\
\hline 32 & T3.2.2.4.2 & Using fuzzy logic \\
\hline 33 & T3.2.2.4.3 & Using genetic algorithms \\
\hline 34 & A3.2.3 & Use a DC-AC converter \\
\hline 35 & A3.2.4 & Connect the output voltage by the load \\
\hline 36 & R3.3 & PV plant monitored and supervised \\
\hline 37 & A3.3.1 & Install a sun sensor \\
\hline 38 & A3.3.2 & Install a temperature sensor \\
\hline 39 & A3.3.3 & Install a voltage sensor \\
\hline 40 & A3.3.4 & Install a current sensor \\
\hline 41 & A3.3.5 & Install a steering $\mathrm{Pc}$ \\
\hline 42 & A3.3.6 & Install an energy meter \\
\hline
\end{tabular}




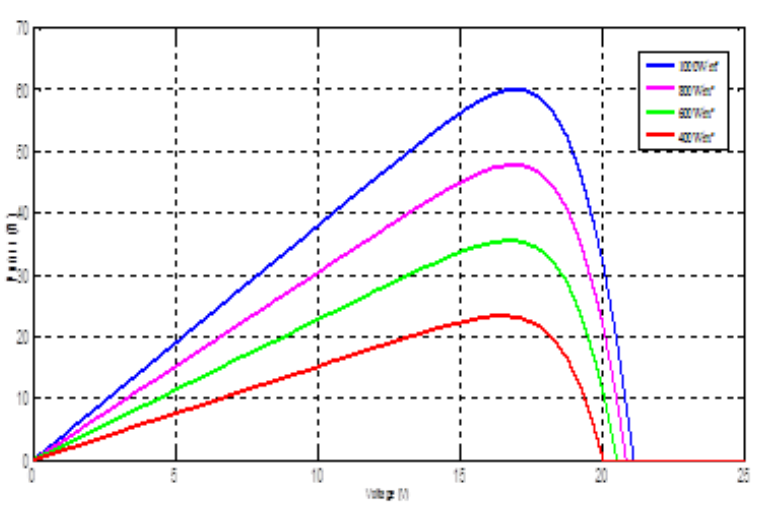

Fig. 7. Characteristics P-V with the variation of solar irradiation

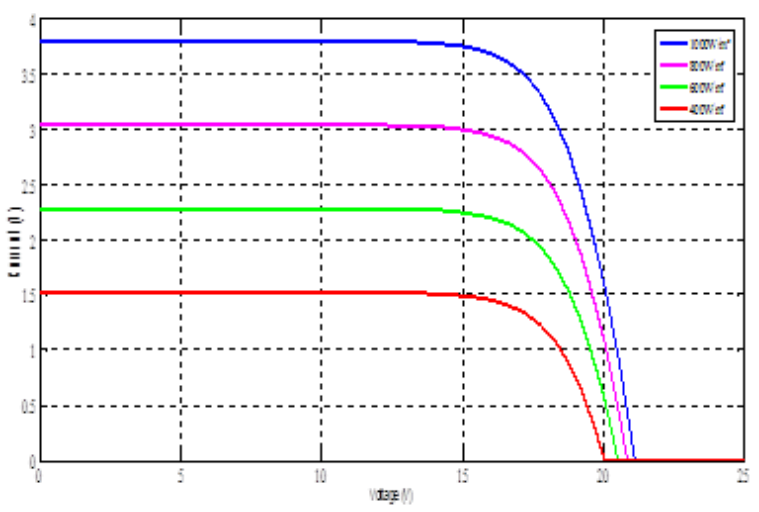

Fig. 8. Characteristics I-V with the variation of solar irradiation

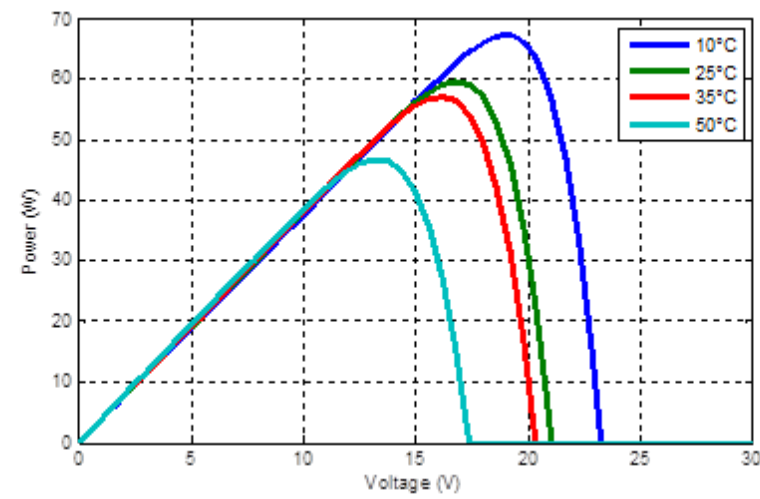

Fig. 9. Characteristic P-V with the temperature variation

\section{CONCLUSION}

On the one hand, this paper presents a systemic modeling with the OOPP method applied on photovoltaic generation system. The system analysis is presented to create a communication interface

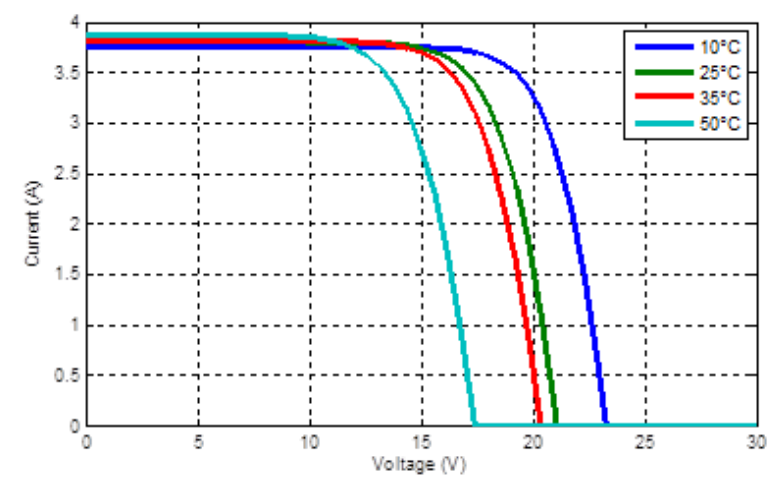

Fig. 10. Characteristics I-V with the temperature variation

Table 4. Specific Objective OS4

\begin{tabular}{|c|c|l|}
\hline 1 & OS4 & Photovoltaic variables identified \\
\hline 2 & R4.1 & $\begin{array}{l}\text { Variables influencing the performance } \\
\text { PV identified }\end{array}$ \\
\hline 3 & A4.1.1 & Identify atmospheric variables \\
\hline 4 & S4.1.1.1 & Identify sunshine \\
\hline 5 & S4.1.1.2 & Identify the operating temperature \\
\hline 6 & A4.1.2 & Identify non-atmospheric variables \\
\hline 7 & S4.1.2.1 & Identify the material from \\
\hline 8 & S4.1.2.2 & Identify Inclination and orientation module \\
\hline 9 & S4.1.2.3 & Identify charge controllers \\
\hline 10 & R4.2 & $\begin{array}{l}\text { Factors photovoltaic dimensioning } \\
\text { identified }\end{array}$ \\
\hline 11 & A4.2.1 & $\begin{array}{l}\text { Identify the behavior of site climatic } \\
\text { parameters }\end{array}$ \\
\hline 12 & A4.2.2 & Identify the load profile \\
\hline 13 & A4.2.3 & Identify installation requirements \\
\hline 14 & A4.2.4 & Identify the budget \\
\hline
\end{tabular}

among researchers, to analyze and plan the photovoltaic system in different stages, to evolve the system in its various steps, to study the installation site and to make the correct choice of components.

On the other hand, a photovoltaic production chain is described with its various phases in its two modes. Thus, Matlab simulation allowed us to study the characteristics of a PV module under optimum conditions and under different climate conditions such as the influence of solar radiation and temperature values on the photovoltaic system characteristics.

In future work, we want to simulate all the photovoltaic production chains and systematically model other renewable products, in order to have a production domain that is well developed and suitable for the smart grid. 


\section{Appendix}

\begin{tabular}{|c|l|}
\hline Symbol & \multicolumn{1}{|c|}{ Description } \\
\hline$a$ & Duty Cycle \\
\hline$A$ & An ideal factor \\
\hline$C_{\text {out }}$ & Boost capacitor \\
\hline$E_{s}$ & The solar insolation in $\mathrm{kW} / \mathrm{m}^{2}$ \\
\hline $\mathrm{I}_{\mathrm{ph}}$ & Light-generated current or photocurrent \\
\hline $\mathrm{I}_{\mathrm{sat}}$ & The cell saturation of dark current \\
\hline $\mathrm{I}_{\mathrm{cc}}$ & The cell short-circuits current at $25^{\circ} \mathrm{C}$ and $1 \mathrm{~kW} / \mathrm{m}^{2}$ \\
\hline $\mathrm{I}_{\mathrm{pv}}$ & PV current \\
\hline $\mathrm{I}_{\text {out }}$ & Boost output current \\
\hline $\mathrm{I}_{\mathrm{Sat}}$ & cell's reverse saturation current \\
\hline $\mathrm{K}$ & A Boltzmann's constant $\left(1.38 \times 10^{-23} \mathrm{~J} / \mathrm{K}\right)$ \\
\hline $\mathrm{L}_{3}$ & Input boosts inductance \\
\hline $\mathrm{q}$ & An electron charge $\left(1.6 \times 10^{-19} \mathrm{C}\right)$ \\
\hline $\mathrm{R}_{\mathrm{sh}}$ & A Shunt resistance \\
\hline $\mathrm{R}_{\mathrm{S}}$ & A series resistance of solar cell \\
\hline $\mathrm{R}_{\mathrm{ch}}$ & The load \\
\hline$T$ & The cell's working temperature \\
\hline $\mathrm{V}_{\mathrm{pv}}$ & PV voltage \\
\hline $\mathrm{V}_{\text {out }}$ & Boost output Voltage \\
\hline & \\
\hline
\end{tabular}

\section{REFERENCES}

1. Adil S., Arthur W. and Hanya A. simplified modeling of a PV panel by using PSIM and its comparison with laboratory test results, Global Humanitarian Technology Conference, 2015.

2. AGCD. Manuel pour l'application de la Planification des Interventions Par Objectifs (PIPO), $2^{\text {ème }}$ Edition, Bruxelles, 1991.

3. Annabi M. PIPO étendue : Méthode Intégrée de Spécification, de Développement et d'Implémentation de Projet (MISDIP), International conference on Sciences and Techniques of Automatic control and computer engineering STA'2003, Sousse, 2003.

4. Asma M., Ali H. and Oualid K. Modélisation et simulation d'un système PV intégré à un réseau BT par la méthode BU Watt-Var découple, 2014.

5. Bellia H., Yousef R. and Fatima M. A detailed modeling of photovoltaic module using Matlab, Journal of Astronomy and Geophysics, 2014.

6. Boualem B., Abdelmadjid C., Jean-Paul G. and Mabrouk H. système solaire photovoltaique connecté au réseau électrique et associé à un filtre actif parallèle, SGE'14, France 2014, 8-10.

7. Das B., Jamatia A. and Chak A. New Pertube and its validation using data from PV module, IJAET, 4(1), 2012, 579-591.

8. Edouard M. and Donatien N. Mathematical modeling and digital simulation of PV solar panel using Matlab software, International Journal of Emerging Technology and Advanced Engineering, 3(9), 2013.

9. Gwinyai D. Modeling of photovoltaic systems, Thesis, The Ohio State University, 2008.

10. Hanen A., Hafedh A., Kais L., Ahmad T. and Mohamed A. étude comparative de cinq algorithmes de commande MPPT pour un système photovoltaique, CIER'13, Tunis, 2013.

11. Jangwoo P., Hong-Geun K., Yongyum C. and Changsum S. Simple modeling and simulation of photovoltaic panels using Matlab/Simulink, Advanced Science and Technology Letters, 73, 2014, 147-155.

12. Kechar E., Azzag E. and Touaibia I. Influence des rayonnements solaires sur le rendement des panneaux photovoltaiques, International Journal of Scientific Engineering and Technology, 3(1), 2015, 71-77.

13. Killich S. and Luczak H. Support of Interorganizational Cooperation via TeamUp at Internet-Based Tool for Work Groups, Proceedings of the 6th internationally Scientific Conference, Berchtesgaden, May 22-25, 2002.

14. Lakhoua M.N. and Ben Jouida T. Refining the objectives oriented project planning (OOPP) into method of informational analysis by objectives, International Journal of the Physical Sciences, 6(33), 2011, 7550-7556.

15. Lakhoua M.N. and Ben Jouida T. Refining the OOPP into Method of Representation of the Information by Objectives, International Transactions on Systems Science and Applications, 7(3), 2011, 295-303.

16. Lakhoua M.N. Systemic analysis of an industrial system: case study of a grain silo, Arabian Journal for Science and Engineering, 38, 2013, 1243-1254.

17. Lakhoua M.N., Jabri I., Battikh T., Maalej L., Mlouhi Y. Study on the use of Systemic Analysis and Image Processing Techniques in a Sports Meeting, European Journal of Scientific Research, 2015, 132(1), 2015.

18. Maalej L., Lakhoua M.N., Chakir I., Battikh T. and Jabri I. planning of a graphics on TV Project of an athletics event, CISTEM2014, Tunis 2014.

19. Ould Mohamed Yahya A., Ould Mohamed A. and Youm I. Etude et modélisation d'un générateur photovoltaique, Revue des energies renouvelables, 11(3), 2008.

20. Peffers K. and Ture Tunanen T. Planning for IS applications: a practical, information theoretical method and case study in mobile financial services, Information \& Management, 42(3), 2005, 483-501.

21. Sahu T.P., Dixit T.V.and Kumar R. Perturb and observe MPPT Algorithm for PV array using cuk converter, Advance in Electronic and Electric Engineering, 4(2), 2014, 213-224. 
22. Stéphane P. Nouvelles architectures distribuées de gestio et de conversion de l'énergie pour les applications photovoltaique, Thèse, Université de Toulouse, Janvier 2009.

23. The Logical Framework Approach (LFA). Handbook for objectives-oriented planning, Norad, Fourth edition, 1999.
24. Vechiu I. Modélisation et analyse de l'integration des energie renouvelables dans un réseau autonome, Thèse, Université du Havre, 2005.

25. Xuan Hieu N. and Mink Phuong N. Mathematical modeling of photovoltaique cell/module/arrays with tags in Matlab/Simulink, Springer, Environmental Systems Research, 2015. 